\title{
TORRES STRAIT'S PRE-COLONIAL POPULATION: THE HISTORICAL EVIDENCE RECONSIDERED
}

\author{
STEVE MULLINS
}

\begin{abstract}
This article argues that a close and informed reading of the historical evidence indicates that David Harris's 1979 estimate of the pre-colonial population of the western islands of Torres Strait is exaggerated, and that Jeremy Beckett's original 1971 estimate is more accurate.
\end{abstract}

The available historical evidence does not allow for a precise estimate of the population of Torres Strait before the colonial occupation of the islands began in the mid-1860s. Although there had been considerable shipping through the region from the 1820 s onwards, and observers did record population figures for various islands, these were often contradictory. That the early figures vary is partly explained by the fact that some visitors to the islands quite simply were inaccurate observers, though to be fair the Islanders' mobility, venturing to sea week-by-week for a variety of reasons as well as in seasonal patterns, made the observer's task difficult. In this early phase of contact outsiders generally only visited the islands briefly to trade, and during these short stays it was impossible for them to tell which Islanders were, like themselves, mere visitors, which were inhabitants, and how many inhabitants were absent in their canoes. As the explorer Strachan said of the pioneer Torres Strait missionary Samuel McFarlane, they often made the mistake of "counting noses rather than residents" (Strachan 1886:97). It follows then that to make even a reasonably accurate estimate of the pre-contact population of Torres Strait from this distance in time it is necessary to have some knowledge of the traditional movements of the Islanders, to be able to make fair judgements about the veracity and competence of those who recorded the original figures, and about when diseases and other population depleting phenomena were likely to have affected the various communities. It is hardly surprising therefore to find that scholars vary in their estimates.

Jeremy Beckett at the 1971 'Bridge and Barrier' conference, was the first academic to estimate Torres Strait's pre-colonial population. On that occasion he did not provide details about method, except to say that his figures were based on observations made by missionaries and others in the early contact period (Beckett 1972:312). He estimated a total of between 3000 and 4000 and this stood as the generally accepted figure until 1987 when he revised it upwards to between 4000 and 5000 after considering research published in 1979 by David Harris of the University of London (Beckett 1987:26). Harris, in the course of describing a pattern of pre-colonial settlement and resource exploitation in order to explain the side-byside existence of hunter-gather-fisher and horticultural communities in Torres Strait, estimated that the combined population of the western islands at approximately 2800 , considerably more than Beckett allowed for in his original overall figure (Harris 1979:90). However, Harris's analysis of the historical evidence suggests that his knowledge of events in the early contact period is patchy at best, and on close scrutiny some of his assumptions regarding the pattern and timing of population depletion cannot be sustained. This paper argues that Harris's figures are exaggerated and that the pre-colonial population of Torres Strait was much closer to Beckett's original 1971 estimate. Perhaps the most straightforward way of demonstrating this point is to examine Harris's estimates island by island, and then to conclude with some general observations. Before doing that however, I should address those few instances where Beckett and I disagree. To make the whole process easier to follow I have included three tables; Beckett's, Harris's and mine (Tables 1, 2 and 3).

Table 1: Population Estimates of Torres Strait Islands during the eary years of contact. There is no information for some islands.

\begin{tabular}{|c|c|c|c|}
\hline Island & $\begin{array}{l}\text { Estimated } \\
\text { Population }\end{array}$ & $\begin{array}{l}\text { Date of } \\
\text { Estimate }\end{array}$ & Source \\
\hline Murray group & $800-1000$ & $1872-3$ & L.M.S. Records \\
\hline Darnley & 500 & pre 1871 & L.M.S. Records \\
\hline Yorke & $80-90$ & 1873 & L.M.S. Records \\
\hline $\begin{array}{c}\text { Warrior and } \\
\text { Yam }\end{array}$ & $200+$ & 1873 & L.M.S. Records \\
\hline Warabir and & 150 & 1846 & Macgillivray \\
\hline Naghir & & & $1852 \quad 11: 35$ \\
\hline Dalrymple & 42 & 1792 & Lee $1920: 182$ \\
\hline $\begin{array}{c}\text { Prince of } \\
\text { Wales }\end{array}$ & 50 & 1846 & Brierly MSS \\
\hline Moa & 500 & pre 1875 & L.M.S. Records \\
\hline Mabuiag & $300+$ & 1872 & L.M.S. Records \\
\hline Saibai & $\begin{array}{l}600 \text { (princi- } \\
\text { pal village) }\end{array}$ & 1873 & $\begin{array}{l}\text { Moresby } \\
1873: 133\end{array}$ \\
\hline Badu & $?$ & - & - \\
\hline Boigu & $?$ & - & - \\
\hline Dauan & $?$ & - & - \\
\hline Aureed & $?$ & - & - \\
\hline Stephen & $?$ & - & - \\
\hline
\end{tabular}


Table 2: Estimated Pre-European (c.1840) Populations and Population Densities of the Westem Torres Strait Islands

\begin{tabular}{|c|c|c|c|c|c|}
\hline & Area & Pop. & $\begin{array}{c}\text { Density } \\
/ \mathbf{k m}^{2}\end{array}$ & $\begin{array}{c}\text { Coast } \\
\mathbf{k m}\end{array}$ & $\begin{array}{l}\text { Density } \\
\text { est./km }\end{array}$ \\
\hline Muralug & 204.9 & 100 & 0.5 & 83 & 1.2 \\
\hline Other islands of the Muralug group & 88.9 & 150 & 1.7 & 79 & 1.9 \\
\hline Muralug group & 293.8 & 250 & 0.8 & 162 & 1.5 \\
\hline Nagir & 1.0 & 200 & 200.0 & 4 & 50.0 \\
\hline Moa & 170.5 & 500 & 2.9 & 52 & 9.6 \\
\hline Muralug-Moa-Nagir Community & 465.3 & 950 & 2.0 & 218 & 4.4 \\
\hline Badu & 104.4 & 670 & 6.4 & 47 & 14.2 \\
\hline Mabuiag & 8.3 & 300 & 36.1 & 10 & 30.0 \\
\hline Badu-Mabuiag Community & 112.7 & 970 & 8.6 & 57 & 17.0 \\
\hline Dauan & 3.0 & 100 & 33.3 & 7 & 14.3 \\
\hline Saibai & 106.4 & 500 & 4.7 & 61 & 8.2 \\
\hline Saibai-Dauan & 109.4 & 600 & 5.5 & 68 & 8.8 \\
\hline Boigu & 85.1 & 350 & 4.1 & 62 & 5.6 \\
\hline Saibai-Dauan-Boigu Community & 194.5 & 950 & 4.9 & 130 & 7.3 \\
\hline Western Torres Strait Islands & 772.5 & 2870 & 3.7 & 405 & 7.1 \\
\hline
\end{tabular}

Table 3: Estimated population of the Torres Strait Islands before European Contact

\begin{tabular}{|c|c|}
\hline \multicolumn{2}{|l|}{ NORTH EASTERN } \\
\hline Mer (Murray), Dauar, Waier & $500-800$ \\
\hline Erub (Darnley) & $400-500$ \\
\hline Ugar (Stephens) & $70-80$ \\
\hline \multicolumn{2}{|l|}{ NORTH WESTERN } \\
\hline Saibai & $600-700$ \\
\hline Dauan (Mt Cornwallis) & 50 \\
\hline Boigu (Talbot) & $150-200$ \\
\hline \multicolumn{2}{|l|}{ CENTRAL WESTERN } \\
\hline Mabuiag (Jervis) & 300 \\
\hline Badu (Mulgrave) & $150-200$ \\
\hline \multicolumn{2}{|l|}{ SOUTH WESTERN } \\
\hline \multicolumn{2}{|l|}{ Muralag (Prince of Wales) } \\
\hline \multicolumn{2}{|l|}{ Nurupai (Horn) } \\
\hline \multicolumn{2}{|l|}{ Giralag (Friday) } \\
\hline \multicolumn{2}{|l|}{ Waibene (Thursday) } \\
\hline \multicolumn{2}{|l|}{ Keriri (Hammond) } \\
\hline Maurura (Wednesday) & $50-100$ \\
\hline Moa (Banks) & $230-300$ \\
\hline \multicolumn{2}{|l|}{ CENTRAL } \\
\hline \multicolumn{2}{|l|}{ Massid (Yorke) } \\
\hline \multicolumn{2}{|l|}{ Aurid (Aureed) } \\
\hline \multirow{2}{*}{\multicolumn{2}{|c|}{$\begin{array}{l}\text { Damut (Dalrymple) } \\
\text { Mauar (Rennel) }\end{array}$}} \\
\hline & \\
\hline \multicolumn{2}{|l|}{ Paremar (Coconut) } \\
\hline \multicolumn{2}{|l|}{ Yam (Turtle-Backed) } \\
\hline \multicolumn{2}{|l|}{ Tutu (Warrior) } \\
\hline \multicolumn{2}{|l|}{ Giaka (Dungeness) } \\
\hline Gaba (Two Brothers) & 200 \\
\hline \multicolumn{2}{|l|}{ Naghir (Mt Emest) } \\
\hline \multirow[t]{2}{*}{ Waraber (Sue) } & $150-200$ \\
\hline & $3100-3800$ \\
\hline
\end{tabular}


My estimate of the total pre-colonial population of Torres Strait is between 3100 and 3800 (Table 3), a few hundred less than Beckett's 1971 estimate at the upper limit. The discrepancy occurs mostly because we disagree about the populations of the Mer (Murray), Dauar, Waier group, and Moa (Banks). Using London Missionary Society records Beckett proposed that the population of Mer, Dauar and Waier was between 800 and 1000 (Beckett 1972:312). His upper figure comes from the missionary, Archibald Murray, and has to be read in the context of the general tendency of pioneer missionaries to exaggerate the Torres Strait population in order to justify, in the first instance, their very presence in the region, and later in the 1870 s the choice of Torres Strait rather than Port Morseby as headquarters of the New Guinea mission. More particularly, Murray only tentatively suggested 1000 in. 1873 at a time when he and the mission were desperate for some good news - indeed he was on the verge of a complete nervous breakdown.

My own estimate of between 500 and 800 for the group is based on a number of recorded observations over more than 60 years. In 1802 Flinders estimated the population of Mer (Murray) and its small neighbours Dauar and Waier to be about 700 (Flinders 1966:111). In 1836 the Charles Eaton castaway, John Ireland, who had lived at Mer for nearly two years, reckoned that island's population to be less than 400 (King 1837:36). Thirty-five years later in 1872 Archibald Murray calculated that the people of Mer, Dauar and Waier, numbered about 800 (Murray 1872), though, as we have seen above, he changed his mind the following year and suggested instead that on Mer alone there "may be over 1000" (Murray 1873). In 1877 his colleague, Samuel McFarlane, contradicted him when he recorded that at the commencement of the pearl shell fishery (ie. in the late 1860s) the population of Mer was supposed to have been about 500 (McFarlane 1877). Murray's 1000 is the odd figure out, and I think it can safely be dismissed as too high.

I also disagree with Beckett's estimate of 500 for Moa (Banks) (Beckett 1972:312). My estimate is no more than 300 . To arrive at his figure Beckett seems to have relied on a statement made in May 1875 by McFarlane that the population of Moa, then about 250, had been reduced by half since the beginning of the fishery, that is since the mid-1860s (McFarlane 1875). Yet McFarlane knew very little about the island and - had never seen any of its inhabitants (McFarlane 1875). His opinion about its population was pure speculation. The people of Moa were primarily foragers who lived in much the same way, and occupied a similar sized territory as the Kaurareg of the Prince of Wales group, and in 1971 Beckett agreed that the Kaurareg numbered less than 100. The castaway, Barbara Thompson, who lived with the Kaurareg for nearly five years in the late 1840 s, indicated that the people of Moa outnumbered those of the Kaurareg, but that they were not very powerful (Moore 1979:162-163,336). Because of this, and because early European visitors to the region rarely encountered the inhabitants of Moa, I think it unlikely that they numbered more than 300 .

In 1987 Beckett revised his 1971 estimate of the total population upwards to between 4000 and 5000 , inline with the figures published in 1979 by David Harris. Harris estimated that the combined population of the western islands of Torres Strait was approximately 2800. My estimate is about 1800 . Working from the south to the north, Harris maintains that the original population of Muralag (Prince of Wales) was about 100 , and I agree with this figure as an upper limit. But he also argues that there were additional populations on the other islands in the Prince of Wales group. To support this he cites the missionary Murray who wrote in 1872 that there were a few people on Nurupai (Horn) and a "considerable number" on Keriri (Hammond) (Harris 1979:91). But Barbara Thompson's account makes it clear that while the inhabitants of Muralag occasionally made gardens on the surrounding islands, none of those islands were permanently inhabited (Moore 1979:336). Harris admits that Murray's statement gave only a hint that there were populations on the other isiands, yet on the basis of it he has inflated the population of the group from 100 to 250 .

Like Beckett in 1971, Harris has accepted McFarlane's statement that the original population of Moa (Banks) was about 500 and that it had been halved by May 1875 . But Harris goes further to extrapolate from this that the populations of Mabuiag (Jervis) and Badu (Mulgrave) similarly had been halved before any reliable estimate was made of their populations (Harris 1979:90-91). I can not agree. Henry Chester began trading with the people of Mabuiag in 1871 and visited the island six times in that year, staying a week each time. Until then they had had only slight contact with outsiders. Indeed Chester remarked that the first European boats visited the island late in 1870. The Islanders had not been employed on pearl-shelling vessels and Chester described them as a healthy, happy and independent people. There is no reason to believe that their population had been halved before. Chester calculated that they numbered about 300 (Chester 1871). Harris's figure of 600 is almost certainly too high.

Harris's estimate of 670 for Badu (Mulgrave) is based on assumptions similar to those he used to arrive at the figure for Mabuiag (Jervis) (Harris 1979:91). But like the people of Mabuiag those of Badu had had only slight contact with outsiders before 1871 , and it is unlikely that by then their numbers had been dramatically reduced by contact with Europeans. In 1871 Chester wrote that they-possessed about a dozen canoes (Chester 1871), each one capable of transporting about 15 people. The Badu community was a subgroup of the Mabuiag community, and Haddon was emphatic that its population must have been smaller than Mabuiag's (Haddon 1904:233-234). Because of 
this, and because of Chester's observations about them, I estimate that they numbered no more than about 200 .

I also disagree with Harris about the population of Boigu (Talbot). Harris accepts the explorer John Strachan's opinion that, prior to his first visit to the island in 1885 , the population was about 350 (Harris 1979:89). Despite Strachan's dismissive comment about McFarlane counting noses, this was nothing more than a guess. The first reliable estimate was made by Chester in 1880. At that time the people of Boigu numbered about 90 (Chester 1880). However, it is almost certain that by then the population had been reduced by a devastating measles epidemic that cut a swath through Torres Strait in June 1875, reducing the population of the whole by at least 20 percent, and by the raids of the Marind-Anim from the west coast of New Guinea which seemed to become more intense in the 1870s (Mullins 1988:387-389, 416-418). Although Boigu is perhaps the most difficult case, my best guess is that prior to June 1875 the population was between 150-200.

It is impossible to know the extent to which introduced diseases affected the population of Torres Strait before the colonial occupation began, but it is unwise to assume, as Harris sometimes does, a constant rate of depletion across a number of islands. Even on neighbouring islands the impact of introduced diseases could vary considerably. For instance, between 1837 and 1875 the population of Erub (Damley) was reduced dramatically from somewhere near 400 to about 150 (King 1836:36; Edwards 1875), while over the same period the figures for Mer are fairly stable. From the 1830 s the Erubians were in regular contact with Europeans, and thus with exotic diseases, because sailing masters using Bligh's entrance, the most popular route through the Strait, usually anchored in the lee of the island before making their morning run west. On more lightly contacted islands away from the main sealanes the population depletion from disease might have been insignificant. The affect of the June 1875 measles epidemic was dramatic precisely because it came at a time when the pearl-shell fishery was well developed. The epidemic swept through the fleet and, unable to continue work, vessels returned to their island bases. If it had occurred even two years earlier perhaps the result would have been far less disastrous. Unfortunately Harris seems to have been unaware that it occurred at all.

It is also wise to tread warily when assessing the impact of recruitment for the early fishery on the Torres Strait population. Work on a pearl-shelling vessel obviously greatly increased the risk of exposure to potentially fatal diseases, both to the individual and his community, but it was not in itself a death sentence. Harris appears, like others before him, to have placed too much faith in Samuel McFarlane's opinion on this matter. However, McFarlane was instrumental in spreading the 1875 measles epidemic through the Strait, and further to Port Moresby. It is impossible to believe that he was unaware of the consequences of his actions, but in his copious correspondence no mention is ever made of the epidemic. Rather, after 1875, he continually shifts responsibility from himself by stressing the role of pearl-shellers in depleting the Torres Strait population through overwork and alcohol. Doubtless, both through contamination and violence, pearl-shellers often reduced the populations of islands where they engaged men, but it is not enough simply to say that pearl-shellers were in an area at a particular time therefore the population of that area diminished from that very moment! Even if the historical sources are less than adequate they deserve closer reading than that.

\section{References Cited}

Beckett, J. 1972 Torres Strait Islanders, D. Walker (ed.), Bridge and Barrier: the Natural and Cultural History of Torres Strait, Canberra, Research School of Pacific Studies, ANU, pp.307-326.

Beckett, J. 1987 Torres Strait Islanders: custom and colonialism, Melbourne, Cambridge University Press.

Chester, H. 10.8.1871. Letter to colonial secretary, Queensland State Archives, COL/A160, inletter 2499 of 1871 .

Chester, H. 31.12.1880. Letter to colonial secretary, Queensland State Archives, COL/A305, inletter 154 of 1881 .

Edwards, C. 11.12.1875 Narrative of the Chevert's Voyage to New Guinea. Town and Country Joumal.

Flinders, M. 1966 (1814) A Voyage to Tema A ustralis...in the Years 1801, 1802, and 1803 in $H M S$ the Investigator, Vol.1, Adelaide, Adelaide Libraries Board.

Haddon, A.C. (ed.) 1904 Sociology, Magic and Religion of the Western Islanders, Reports of the Cambridge Anthropological Expedition to Torres Straits, Vol.5, Cambridge, Cambridge University Press.

Harris, D. 1979 Foragers and Farmers in the Western Torres Strait Islands: An Historical Analysis of Economic, Demographic, And Spatial Differentiation. P.C. Burnham \& R.F. Ellen (eds.), Social and Ecological Systems. London, Academic Press.

King, P.P. (ed.), 1837 A Voyage to Torres Strait in Search of the Survivors of the ship 'Charles Eaton'. Sydney, Statham.

McFarlane, S. 26.10.1874 2nd Voyage of the Ellengowan. Council For World Mission Archives, Papua Journals 1871-1901.

McFarlane, S. 10.5.1875 6th Voyage of the Ellengowan. 10 May 1875, Council For World Mission Archives, Papua Joumals 1871-1901. 
McFarlane, S. 18.6.1877. Letter to foreign secretary, L.M.S.. Council For World Mission Archives, Papua Letters 1872-1927, B2 F1 Jc.

Moore, D. 1979 Islanders and Aborigines at Cape York. Canberra, AIAS.

Mullins, S. 1988 Torres Strait 1864-1884: a history of occupation and culture contact. PhD, UNE.

Murray, A.W. 1872 A Voyage from the Loyalty Islands to Cape York. Council For World Mission Archives, Papua Journals 1871-1901.

Murray, A.W. 14.5.1873 Letter to foreign secretary, L.M.S.. Council For World Mission Archives, Papua Journals 1871-1901.

Strachan, J: 1886 Exploration in New Guinea. Geographical Society of Australasia, Vol.1, p.84-99.

Steve Mullins

Department of Humanities

University of Central Queensland

Rockhampton Queensland 4702 